\title{
Determination of vegetation cover index under different soil management systems of cover plants by using an unmanned aerial vehicle with an onboard digital photographic camera
}

\section{Determinação do índice de cobertura vegetal em sistemas de manejo do solo com plantas de cobertura, utilizando veículo aéreo não tripulado com câmera fotográfica digital embarcada}

\author{
Adnane Beniaich'; Marx Leandro Naves Silva ${ }^{2 *}$; Fabio Arnaldo Pomar Avalos \\ Michele Duarte de Menezes ${ }^{4}$; Bernardo Moreira Cândido ${ }^{3}$
}

\begin{abstract}
The permanent monitoring of vegetation cover is important to guarantee a sustainable management of agricultural activities, with a relevant role in the reduction of water erosion. This monitoring can be carried out through different indicators such as vegetation cover indices. In this study, the vegetation cover index was obtained using uncalibrated RGB images generated from a digital photographic camera on an unmanned aerial vehicle (UAV). In addition, a comparative study with 11 vegetation indices was carried out. The vegetation indices CIVE and EXG presented a better performance and the index WI presented the worst performance in the vegetation classification during the cycles of jack bean and millet, according to the overall accuracy and Kappa coefficient. Vegetation indices were effective tools in obtaining soil cover index when compared to the standard Stocking method, except for the index WI. Architecture and cycle of millet and jack bean influenced the behavior of the studied vegetation indices. Vegetation indices generated from RGB images obtained by UAV were more practical and efficient, allowing a more frequent monitoring and in a wider area during the crop cycle.
\end{abstract}

Key words: Vegetation cover index. RGB image. Vegetation index. Unmanned aerial vehicle.

\section{Resumo}

O monitoramento permanente da cobertura vegetal é importante para garantir o manejo sustentável das atividades agrícolas, com relevante papel na redução da erosão hídrica. Este monitoramento pode ser realizado por meio de diferentes indicadores, como os índices de cobertura vegetal. Nesse artigo o índice de cobertura de vegetação foi obtido usando imagens RGB não-calibradas, geradas a partir de câmera fotográfica digital embarcada em um veículo aéreo não tripulado (VANT). Além disso, foi feito um estudo comparativo de 11 índices de vegetação. Os índices de vegetação CIVE e EXG apresentaram melhor desempenho e o índice WI apresentou o pior desempenho na classificação da vegetação durante o ciclo das culturas de feijão-de-porco e milheto, conforme a acurácia global e o coeficiente Kappa. Os

${ }^{1}$ Eng $^{\circ}$ Agr $^{\circ}$, Discente de Doutorado, Programa de Pós-Graduação em Ciência do Solo, Universidade Federal de Lavras, UFLA, Lavras, MG, Brasil. E-mail: beniaich@gmail.com

2 Prof. Titular, Departamento de Ciência do Solo, UFLA, Lavras, MG, Brasil. E-mail: marx@dcs.ufla.br

3 Discentes de Doutorado, Programa de Pós-Graduação em Ciência do Solo, UFLA, Lavras, MG, Brasil. E-mail: fa.ingeo@gmail. com; bernardocandido@gmail.com

4 Prof ${ }^{a}$ Adjunta, Departamento de Ciência do Solo, UFLA, Lavras, MG, Brasil. E-mail: michele.menezes@dcs.ufla.br

* Author for correspondence 
índices de vegetação se apresentaram como uma ferramenta eficaz na obtenção dos índices de cobertura de solo, quando comparados ao método padrão de Stocking, exceto para o índice WI. A arquitetura e o ciclo das culturas milheto e o feijão-de-porco influenciaram no comportamento dos índices de vegetação estudados. Os índices de vegetação gerados à partir de imagens RGB obtidas por VANT mostraram ser mais práticos e eficientes, permitindo o monitoramento com maior frequência e abrangência de área durante o ciclo das culturas.

Palavras-chave: Índice de cobertura vegetal. Imagem RGB. Índice de vegetação. Veículo aéreo não tripulado.

\section{Introduction}

The permanent monitoring of vegetation cover is important to guarantee a sustainable management of agricultural activities, with a relevant role in the reduction of water erosion (CARDOSO et al., 2012; FAUSTOLO et al., 2017; GUIMARAES et al., 2017; SPERANDIO et al., 2012). This monitoring can be carried out by different indicators (CARDOSO et al., 2012; LIMA et al., 2014; MARRERO et al., 2009; PASSOS et al., 2015) such as vegetation cover indices, which represent the percentage of area covered by vegetation in relation to the total surface area of study (ZHONGMING et al., 2010).

In this context, different methods can be used to determine vegetation cover index such as the Stocking method (STOCKING, 1994) or UAV onboard camera (CARUSO et al., 2017). By the Stocking method, measurements are performed in situ, providing relevant information, but with high delays in data acquisition and a low spatial cover of the area. On the other hand, unmanned aerial vehicles (UAVs) and onboard digital cameras have low operating costs, allowing a fast data acquisition with a significant spatial cover, whose images and by-products are obtained in a simple way (BENDIG et al., 2015). Another advantage is a higher temporal resolution, which provides important subsidies for decision making (YU et al., 2013).

When comparing images obtained by multi or hyperspectral cameras with those by RGB (Red Green Blue) on UAV, the latter carries limited spectral information. In contrast, its more affordable price, high spatial resolution (centimeters), as well as the possibility of obtaining different vegetation indices in the visible spectrum have increased its use, and studies are needed to better define methodologies and indices for different vegetation cover situations (DANDOIS et al., 2015).

Vegetation indices are formed from combinations of spectral values aiming at obtaining a single value, which allows easily interpreting the quantity or quality of the vegetation within a pixel (CAMPBELL; WYNNE, 2011). Furthermore, these indices have been used to estimate the vegetation cover in pixel-based images, which include vegetated or non-vegetated areas. According to Torres-Sánchez et al. (2014), once the images have a high resolution, in which each pixel covers only the vegetation or bare soil, the proportion of pixels with this information combined is reduced.

Regarding the vegetation cover indices, Cardoso et al. (2012) assessed jack bean and millet as cover crops and observed different soil losses due to water erosion as a function of different soil protection. Thus, changes in vegetation cover directly affect the surface runoff rate (SANTOS et al., 2000). Considering the importance of these cover plants and the lack of information regarding their vegetation cover dynamics, this study aimed to calculate and assess different vegetation indices of the visible spectrum and determine the vegetation cover index from aerial images obtained by UAVs in management systems of cover plants. 


\section{Material and Methods}

Study area

The experiment was conducted in the Federal University of Lavras (UFLA) in Lavras, Minas Gerais, Brazil, located between the coordinates $21^{\circ} 13^{\prime} 20^{\prime \prime} \mathrm{S}$ and $44^{\circ} 58^{\prime} 17^{\prime \prime} \mathrm{W}$ and with an average altitude of $925 \mathrm{~m}$. The study area consisted of plots $4.0 \mathrm{~m}$ wide and $12.0 \mathrm{~m}$ long (Figure 1). Treatments consisted of a bare soil (non-vegetation class) and the crops jack bean (Canavalia ensiformis L.) and millet (Pennisetum glaucum L.) (vegetation class), with three replications each. Cover plants were manually sown at the beginning of November 2015.

Figure 1. Orthophoto of the experimental plots with the treatments jack bean, millet, and bare soil.

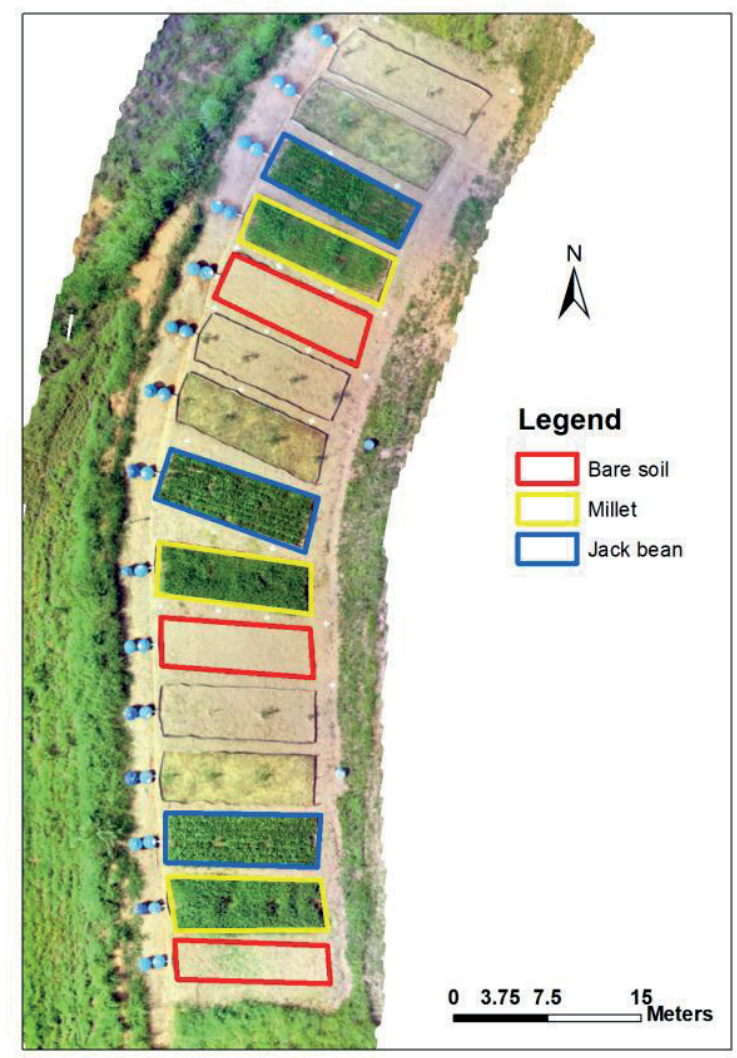

Image acquisition by UAV

Image acquisition was performed by using the unmanned aircraft vehicle (UAV) DJI Phantom 3 professional, serial number: p76ddc18b271, register certificate non-recreational at the National Civil Aviation Agency of Brazil (ANAC), number PP-011111110, according to the methodology proposed by Bendig et al. (2015). The photographic parameters were an aperture of $\mathrm{f} / 2.8$, shutter speed of $1 / 290 \mathrm{~s}$, ISO of 100 , white balance of $4500 \mathrm{~K}$, and focal length of $3.6 \mathrm{~mm}$. Flights were carried out during the crop cycle at $5,15,30,75,105$, and 135 days after sowing (DAS) (Figure 1).

Six flights with a height of $15 \mathrm{~m}$ were carried out. For image georeferencing, 18 control points were used. Between 150 and 200 photos were recorded per flight with $80 \%$ overlap. In the next step, the program PhotoScan Pro1.2.6 (AGISOFT, 2017) was used for image processing. 


\section{Vegetation indices}

Nine indices and two combinations were used in this study. RGB bands were normalized to calculate the chromatic levels (ARROYO et al., 2016; WOEBBECKE et al., 1995) (Equation 1).

$r=\frac{R}{R+G+B}, g=\frac{G}{R+G+B}$, and $b=\frac{R}{R+G+B}$

Where $\mathrm{r}, \mathrm{g}$, and $\mathrm{b}$ are the normalized values of the bands R (red), G (green), and B (blue), respectively.

In order to find the best optical contrast between plants and soil and discriminate them automatically, the indices Excess Green (ExG) (Equation 2) and Woebbecke Index (WI) (Equation 3) were used according to Woebbecke et al. (1995).

$$
\begin{aligned}
& \mathrm{ExG}=2 \mathrm{~g}-\mathrm{r}-\mathrm{b} \\
& \mathrm{WI}=\frac{\mathrm{g}-\mathrm{b}}{\mathrm{r}-\mathrm{g}}
\end{aligned}
$$

The index Excess Green Minus Excess Red (EXGR), proposed by Meyer and Neto (2008) (Equation 4), was used to distinguish plant canopy from different soil or residue backgrounds.

$$
\mathrm{EXGR}=\mathrm{ExG}-1.4 \mathrm{r}-\mathrm{g}
$$

The index Color Index of Vegetation (CIVE) (KATAOKA et al., 2003) was based on the principal component analysis of the information contained in the RGB bands (Equation 5).

$$
\mathrm{CIVE}=0.441 \mathrm{r}-0.881 \mathrm{~g}+0.385 \mathrm{~b}+18.78745
$$

For estimating the vegetation fraction, the Normalized Green-Red Difference Index (NGRDI) was used (GILABERT et al., 2002) (Equation 6).

$$
\mathrm{NGRDI}=\frac{\mathrm{G}-\mathrm{R}}{\mathrm{G}+\mathrm{R}}
$$

Based on the physical study of the image, Marchant and Onyango (2000) developed the Vegetativen index (VEG) (Equation 7).

$$
\mathrm{VEG}=\frac{\mathrm{g}}{\mathrm{r}^{\mathrm{a}} \mathrm{b}^{(1-\mathrm{a})}}
$$

where a is a constant with a reference value of 0.667 .

Using different results obtained in studies on the aforementioned indices, Guijarro et al. (2011) proposed the indices COMB1 and COMB2 (Equations 8 and 9).

$$
\begin{aligned}
& \mathrm{COMB} 1=0.25 \mathrm{ExG}+0.3 \mathrm{EXGR}+0.33 \mathrm{CIVE}+0.12 \mathrm{VEG} \\
& \mathrm{COMB} 2=0.36 \mathrm{ExG}+0.47 \mathrm{CIVE}+0.17 \mathrm{VEG}
\end{aligned}
$$

In addition, the indices Ratio Green/Red (GR) (Equation 10) and SAVI green (SAVI) modified by Li et al. (2010) (Equation 11) were tested.

$$
\mathrm{GR}=\frac{\mathrm{G}}{\mathrm{R}}
$$

$$
\text { SAVI }=\frac{1.5 *(G-R)}{(G+R+0.5)}
$$

In this study, the index hue (HUE) was also used, constituting one of the components of HSV (Hue, Saturation, Value) color space. HSV model defines a color space in three components: hue (HUE), which determines the type of color and varies from 0 to $360^{\circ}$; saturation (S), which shows the color vibration and varies from 0 to 1 ; and value $(\mathrm{V})$, which is the color brightness and ranges from 0 to 1 . HUE was determined using the methodology proposed by Purcell et al. (2011) (Equation 12).

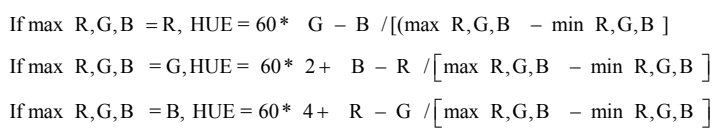

Assessment of vegetation indices to generate vegetation classes

Initially, from the mosaic of six orthophotos, 100 random points were extracted with values of vegetation indices for each of the nine plots. These values were submitted to the logistic regression in order to generate probability intervals from 0 to 1 , as Equation 13 (HILBE, 2009):

$$
\mathrm{P}=\frac{1}{\left(1+\mathrm{e}^{-\mathrm{z}}\right)}, \mathrm{z}=\mathrm{b}_{0}+\mathrm{b}_{1} \mathrm{x}
$$

Where $\mathrm{P}$ is the probability of an event, which, in this case, is vegetation or non-vegetation, $\mathrm{z}$ is the linear function of the exploratory variable $x, b_{0}$ is the intercept, and $b_{1}$ is the angular coefficient. Thus, from the values of $\mathrm{z}$ for each vegetation index, the value $P=0.5$ served as a limit to distinguish 
vegetation classes (vegetation or non-vegetation) (JAFARI GOLDARAG et al., 2016). Since the data has a binary, the logistic regression is adequately applied to the data.

For validating the vegetation classes, 50 random points were extracted from the orthophotos containing vegetation classes for each plot. Classification accuracy was obtained by calculating the Kappa coefficient (LANDIS; KOCH, 1977) and overall accuracy (FOODY, 2010).

\section{Cover index calculation}

Two methods were used to calculate the vegetation cover index. The first method used the methodology proposed by Stocking (1994) during crop cycle (jack bean and millet) in relation to the days after sowing (DAS).

In addition, the vegetation cover index was determined for each vegetation index (generated by logistic regression) (CI VI) (Equation 14).

$$
\text { CI VI }=\frac{\text { Pixels classified as vegetation }}{\text { Totalpixels of the plot }}
$$

The comparison between the cover indices was performed by means of linear regression (coefficient of determination, $\mathrm{R}^{2}$ ) and Pearson correlation, in addition to the calculation of the residual sum of squares (RSS) for each plot (FERREIRA, 2005).

\section{Results and Discussion}

\section{Assessment of vegetation indices in the visible}

Figure 2 shows that the maps generated from the combinations of RGB bands allowed recording the variability of responses of vegetation indices in relation to vegetation in each plot. Table 1 shows the descriptive statistics of vegetation indices for different classes (vegetation or non-vegetation).

The indices WI and HUE presented a higher variation and high values of the standard deviation when compared to the others. Moreover, it is possible to observe the contrast between indices when analyzed for vegetation and non-vegetation, considering their average values and respective standard deviation. Thus, most of the indices presented a difference between the average values in each class (Table 1). This reinforces the potential of the indices in discriminating different types of vegetation cover. The indices GR, HUE, and WI, on the other hand, did not present an adequate distinction between classes.

Torres-Sánchez et al. (2014) assessed the accuracy of vegetation indices and obtained average values of vegetation index limits around -0.01 , $18.73,6.12,9.05,0.16,5.21,1.17$, and -0.79 for NGRDI, CIVE, COM1, COM2, EXG, WI, VEG, and EXGR, respectively. The index WI found in our study stood out with a great difference between the results of the aforementioned study, unlike the other indices, which present little difference. Saberioon et al. (2014) found average values of 0.002, 0.471, and 0.210 for NGRDI, EXG, and EXGR, respectively, in rice. These values are in line with those obtained in our study. On the other hand, Hunt (2005) found an average NGRDI value of 0.05 in corn and 0.13 in soybean. Motohka et al. (2010) analyzed time variation of the index NGRDI for 4 years and found values ranging from 0.371 to -0.112 . In our study, the index NGRDI presented an amplitude between 0.25 and -0.46 . 
Figure 2. Maps of the visible vegetation indices CIVE (a), COMB1 (b), COMB2 (c), ExG (d), EXGR (e), GR (f), HUE (g), NGRDI (h), SAVI (i), VEG (j), and WI (k) calculated on February 2, 2016 from the RGB composition.

a

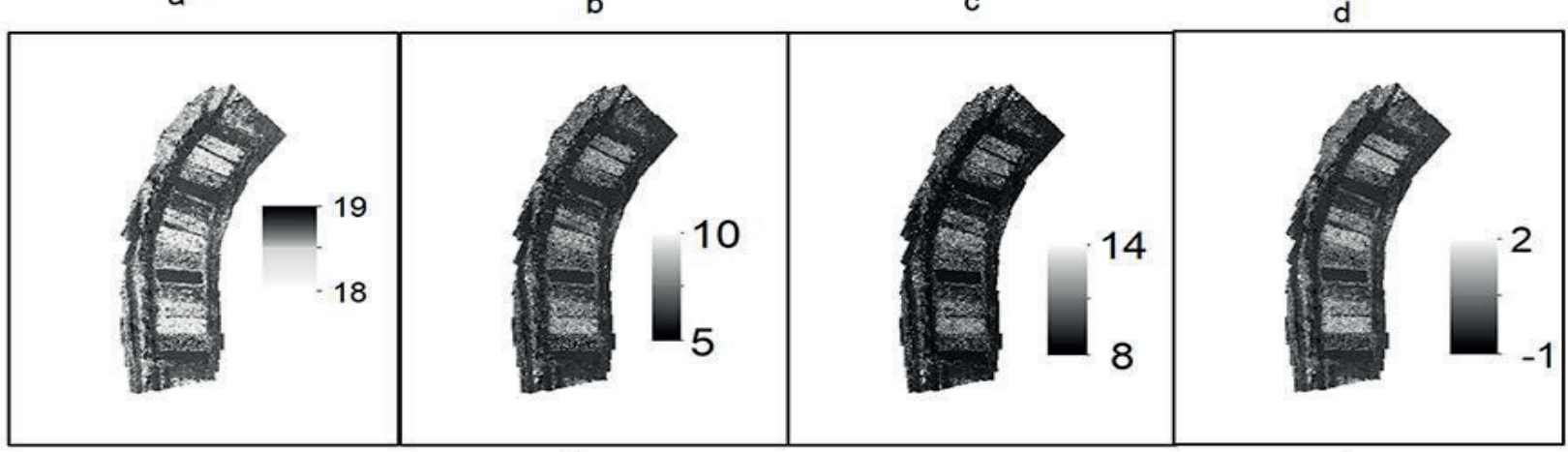

e

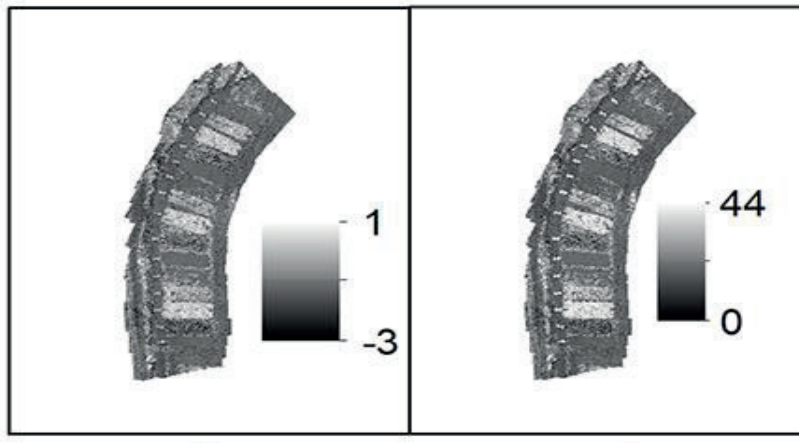

g

h

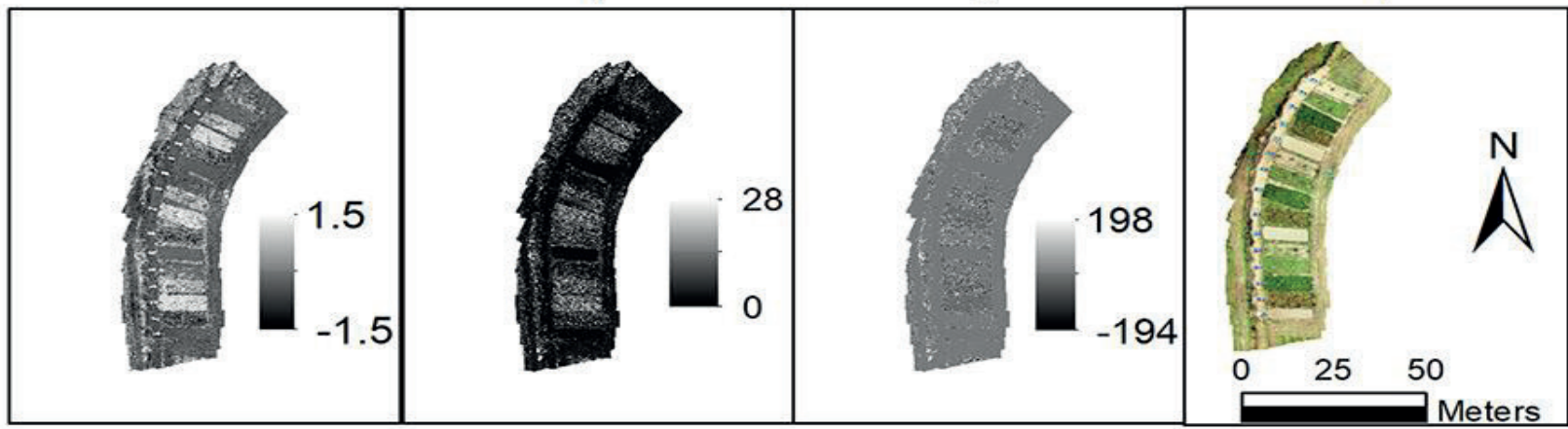

Figure 3 shows the Violin Plot of each class (vegetation or non-vegetation) in relation to vegetation indices, allowing a better presentation of the variability of point distribution of indices in each class. The indices WI, VEG, and GR presented a similarity in the distribution of both vegetation and non-vegetation classes, with statistically equal median values in each of them, demonstrating their low performance. The other indices presented the same tendency of point distribution, with a great amplitude in the vegetation class and a low variability in the non-vegetation class, showing a concentration of points in the median. As a consequence, these indices may present good classifiers. 
Table 1. Descriptive statistical analysis of vegetation indices visible in both vegetation and non-vegetation classes.

\begin{tabular}{lcccccccc}
\hline \multirow{2}{*}{ Parameter $^{1}$} & \multicolumn{2}{c}{ Mean } & \multicolumn{2}{c}{ SD } & \multicolumn{2}{c}{ Maximum } & \multicolumn{2}{c}{ Minimum } \\
\cline { 2 - 8 } & VC & NVC & VC & NVC & VC & NVC & VC & NVC \\
\hline CIVE & 18.63 & 18.77 & 0.09 & 0.03 & 18.92 & 18.91 & 18.18 & 18.44 \\
COMB1 & 6.23 & 6.04 & 0.15 & 0.04 & 7.46 & 6.74 & 5.80 & 5.82 \\
COMB2 & 9.16 & 8.99 & 0.15 & 0.03 & 10.48 & 9.74 & 8.90 & 8.89 \\
EXG & 0.33 & 0.01 & 0.21 & 0.06 & 1.38 & 0.79 & -0.31 & -0.29 \\
EXGR & -0.66 & -0.92 & 0.20 & 0.08 & 0.39 & -0.35 & -1.51 & -1.43 \\
GR & 1.18 & 0.80 & 0.36 & 0.09 & 6.00 & 1.54 & 0.33 & 0.37 \\
HUE & 61.63 & 34.29 & 30.64 & 37.89 & 133.33 & 358.33 & 0.17 & 0.00 \\
NGRDI & 0.06 & -0.12 & 0.13 & 0.06 & 0.71 & 0.21 & -0.50 & -0.46 \\
SAVI & 0.09 & -0.17 & 0.20 & 0.09 & 1.06 & 0.32 & -0.74 & -0.69 \\
VEG & 1.67 & 0.98 & 0.68 & 0.14 & 8.47 & 4.66 & 0.69 & 0.65 \\
WI & -1.80 & 1.43 & 12.46 & 4.27 & 171.00 & 55.00 & -96.00 & -69.00 \\
\hline
\end{tabular}

${ }^{1} \mathrm{SD}$ : standard deviation; ${ }^{2} \mathrm{VC}$ : vegetation class, NVC: non-vegetation class.

Figure 3. Violin plot of the vegetation indices CIVE (a), COMB1 (b), COMB2 (c), ExG (d), EXGR (e), GR (f), HUE (g), NGRDI (h), SAVI (i), VEG (j), and WI (k) in relation to vegetation (VC) and non-vegetation (NVC) classes.

(a)

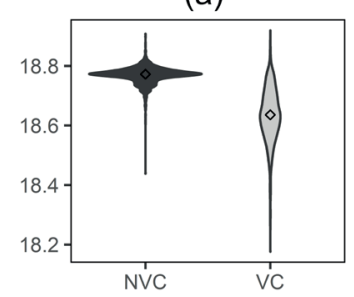

(d)

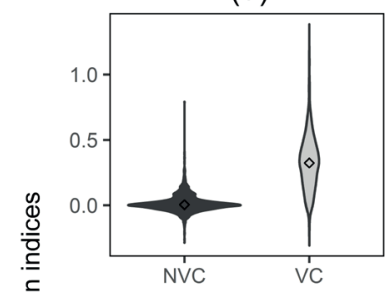

(g)

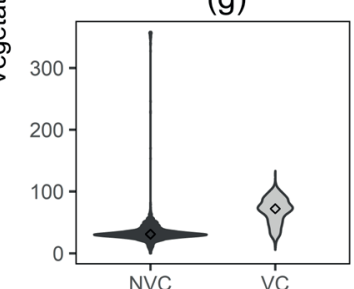

(j)

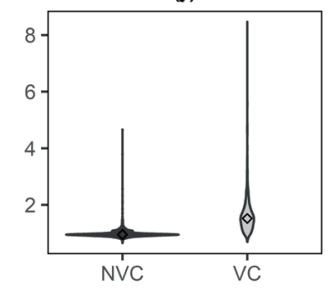

(b)

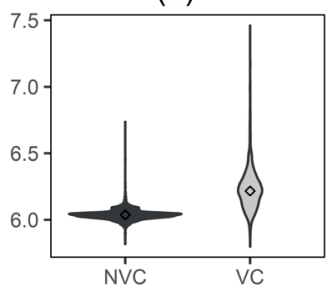

(e)

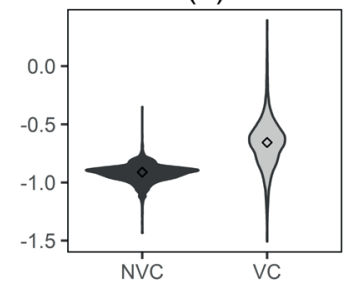

(h)

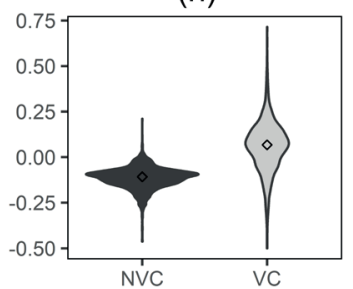

(k)

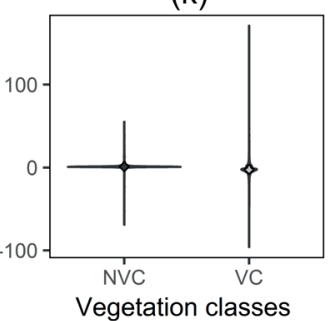

(c)

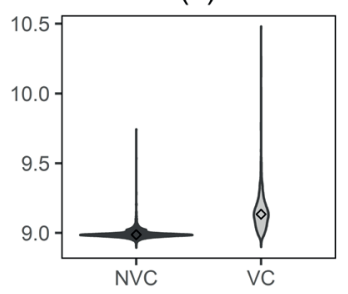

(f)

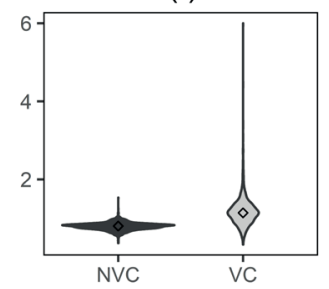

(i)

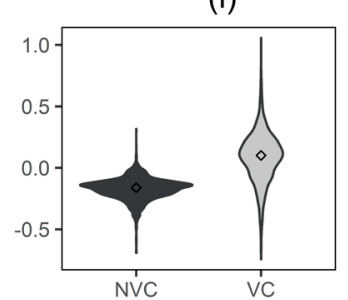

Vegetation classes

$\bullet$ NVC 
The curve shape of the logistic regression model the relationship is direct between both variables, but ( $\mathrm{S}$ or $\mathrm{Z}$ curves) is shown in Figure 4. The type of it is likely to be classified as vegetation when the relationship between the binomial variable and index value is raised. When the opposite occurs, the vegetation index response related to $b_{1}$ value i.e. the $b_{1}$ value is negative $\left(b_{1}<0\right)$, as in the indices is shown in Table 2. When the $b_{1}$ value is positive CIVE and WI, their relation with vegetation class is $\left(b_{1}>0\right)$, as in the indices COMB1, COMB2, and EXG, inverted (Figure 4).

Figure 4. Logistic regression models of the vegetation indices CIVE (a), COMB1 (b), COMB2 (c), ExG (d), EXGR (e), GR (f), HUE (g), NGRDI (h), SAVI (i), VEG (j), and WI (k) in the visible.

(a)

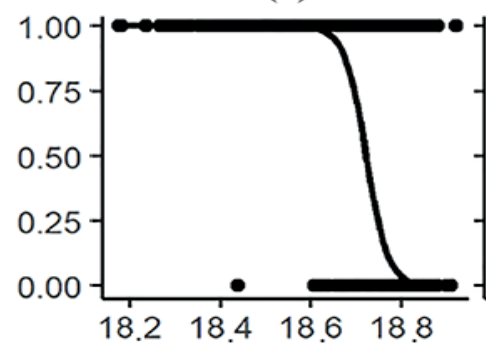

(d)

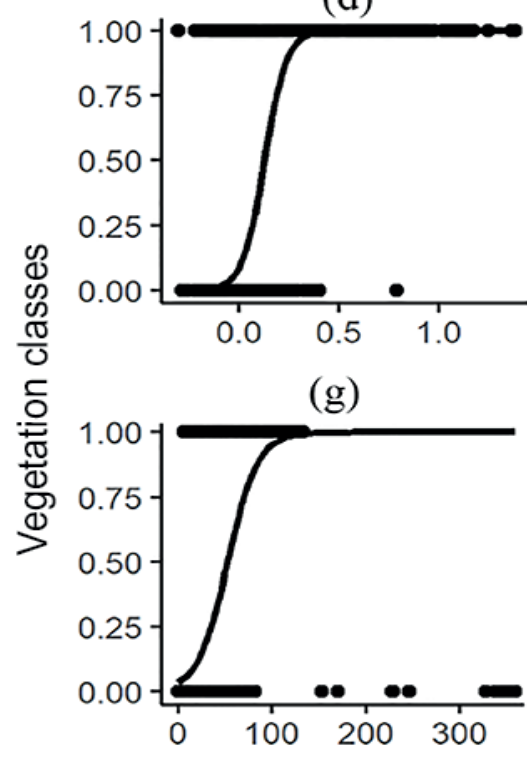

(j) (b)

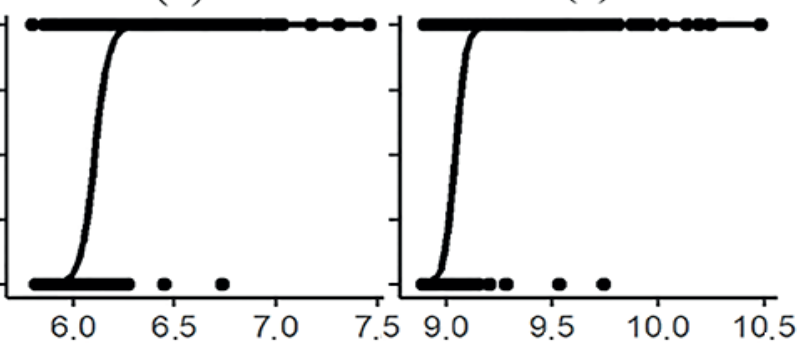

(e)

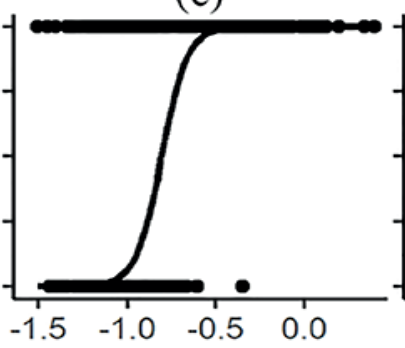

(h)

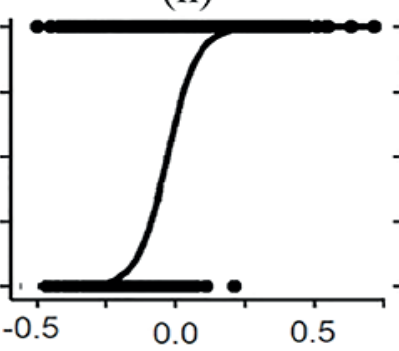

(k)

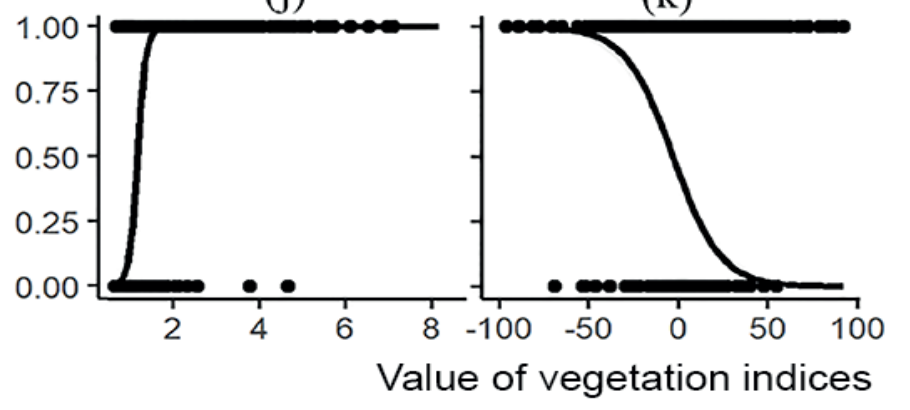

(f)

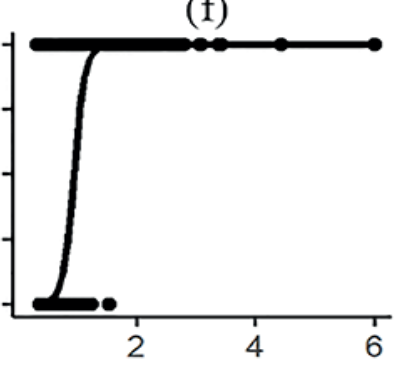

(i)

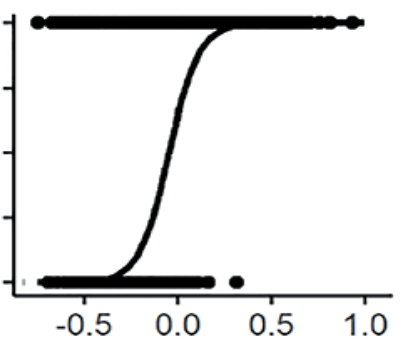


Table 2. Parameters of the logistic regression models for each vegetation index in the visible.

\begin{tabular}{lcccc}
\hline \multicolumn{1}{c}{ Parameter $^{1}$} & $\mathrm{~b}_{0}$ & $\mathrm{~b}_{1}$ & Limit values & $\mathrm{p}$ value \\
\hline NGRDI & 0.612 & 18.856 & -0.032 & $<0.001$ \\
EXG & -2.304 & 18.357 & 0.126 & $<0.001$ \\
CIVE & 788.240 & -42.110 & 18.719 & $<0.001$ \\
EXGR & 11.220 & 13.910 & -0.807 & $<0.001$ \\
WI & -0.237 & -0.069 & -3.439 & $<0.001$ \\
VEG & -12.10 & 10.35 & 1.169 & $<0.001$ \\
COMB1 & -177.68 & 29.11 & 6.104 & $<0.001$ \\
COMB2 & -365.30 & 40.40 & 9.042 & $<0.001$ \\
HUE & -3.299 & 0.063 & 52.561 & $<0.001$ \\
GR & -10.18 & 10.79 & 0.943 & $<0.001$ \\
SAVI & 0.612 & 12.599 & -0.049 & $<0.001$ \\
\hline
\end{tabular}

${ }^{1} \mathrm{~b}_{0}$ and $\mathrm{b}_{1}$ are parameters of the equation $\mathrm{z}=\mathrm{b}_{0}+\mathrm{b}_{1} \mathrm{x}$.

Classification assessment of vegetation indices in the visible spectrum

Regarding the accuracy of the classification performed through vegetation indices (Figure 5), the indices CIVE and EXG stood out with the highest values of Kappa coefficient (0.806 and 0.805, respectively). Subsequently, the indices VEG, COMB2, and COMB1 were grouped with values of $0.789,0.788$, and 0.779 , respectively. In a third group were the indices HUE, NGRDI, SAVI, and GR, with values of $0.737,0.726,0.726$, and 0.719 , respectively. The index WI presented the lowest value (0.325). The results of the overall accuracy confirmed the same order of the values obtained by Kappa coefficient, with the highest value for CIVE (0.906) and the lowest value for WI (0.694). In Figure 5, the results of the index WI were not presented due to their low magnitude.

Figure 5. Relationship between Kappa indices and overall accuracy of the calculated vegetation indices.

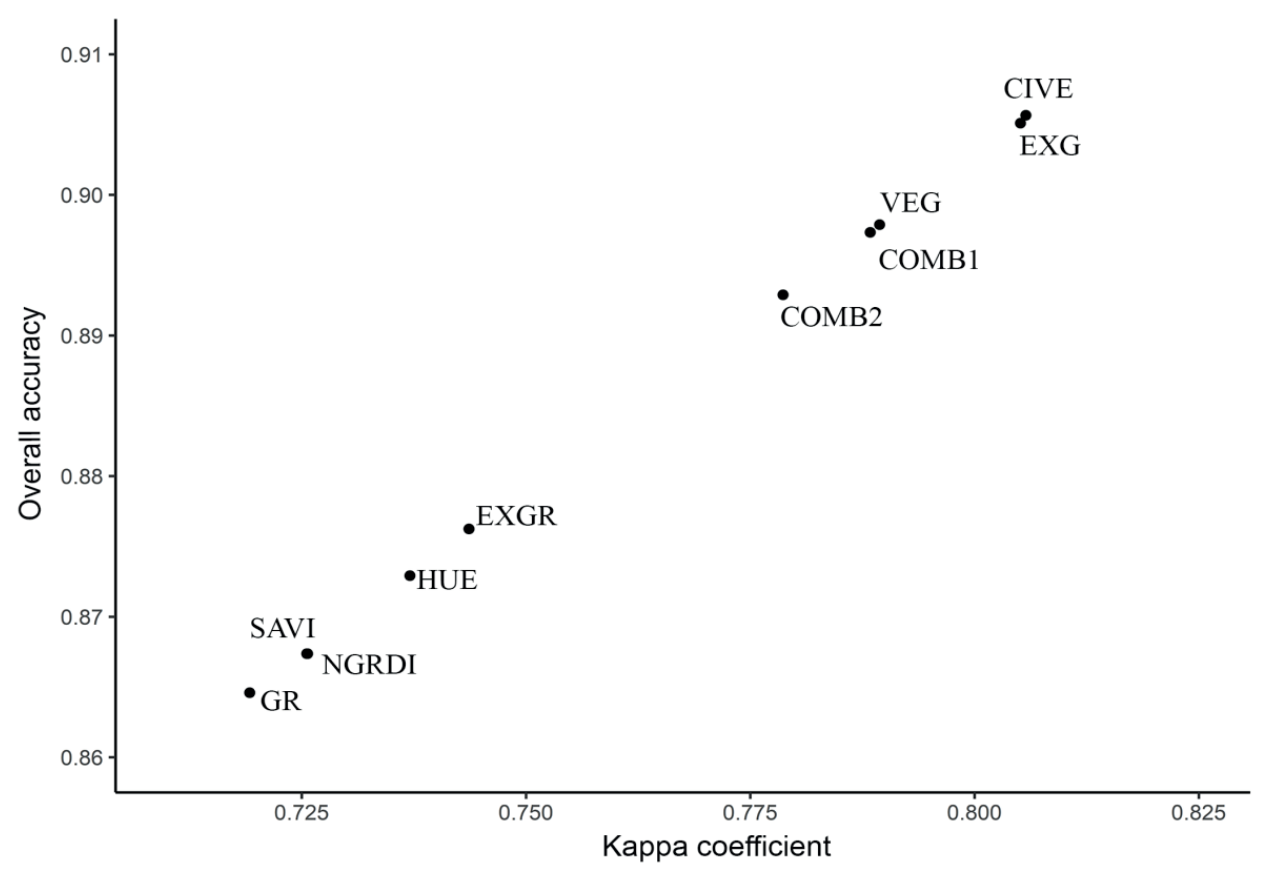


According to Landis and Koch (1977) classification, Kappa coefficient values between 0.81 and 1.0 showed an almost perfect agreement. However, values between 0.61 and 0.80 presented a substantial agreement, which means the presence of a good relationship between the classification methods. The indices that presented this level of agreement were CIVE, EXG, VEG, COMB2, COMB1, EXGR, HUE, SAVI, NGRDI, and GR. Values of Kappa coefficient between $0.41-0.60$ and $0.21-0.40$ represent a moderate and reasonable agreement, respectively. The index WI, in addition to presenting a reasonable level of agreement, showed a low position in the coefficient scale. Therefore, WI is not recommended for classifying the vegetation for conditions similar to those of this experiment.

The overall accuracy and Kappa coefficient obtained by the indices CIVE and EXG showed a good performance to classify the vegetation. This may be explained by their ability to mitigate the effects of lighting and variability in soil reflectance. Although vegetation depends on G-band reflectance (HUNT, 2005), models that combine the three RGB bands are more accurate due to the variability of soil reflectance. These results are in accordance with those obtained by Kazmi et al. (2015).

All indices calculated from the normalized bands presented an overall accuracy above 0.85 and Kappa coefficient above 0.70 , except for the index WI. Woebbecke et al. (1995) obtained a better performance of the index EXG in classifying monoand dicotyledonous by using different backgrounds in relation to the indices WI and HUE.
According to Hague et al. (2006), the use of the index VEG, generated from images of cameras boarded in a tractor for weed classification, allowed a good correlation between the automatic method and manual classification. However, these authors observed that the use of the index VEG overestimated crop and weed density due to the camera angle in relation to the vertical projection.

Regarding the effect of development stages of jack bean and millet cycles, the indices presented a similar behavior over DAS, except for WI (Figure 6). The curves of vegetative dynamics, represented by vegetation indices, can be grouped into the intervals $0-30$ and 30-135 DAS. In the first interval, an increase in the values of overall accuracy and kappa coefficient were observed as DAS increased, which is due to an increase in leaf area and vegetation cover index. In the second interval, there is a decrease in vegetation index accuracy, which, according to Zheng et al. (2017), is related to a decrease of plant size, leaf area, cover index, and leaf dryness. However, the index WI showed a great variation over crop cycle, always presenting a less accuracy when compared to the others.

According to Motohka et al. (2010), Hunt et al. (2005), and Tucker (1979), the applicability of vegetation indices to different crops may be limited to a certain stage of plant development. Zheng et al. (2017) showed that the vegetation indices EXG, CIVE, and EXGR allowed a vegetation segmentation in corn, in which the highest accuracy values were obtained at the first crop development stages. 
Figure 6. Overall accuracy (a) and Kappa coefficient (b) of vegetation indices in relation to the days after sowing (DAS) of cover plants.

(a)

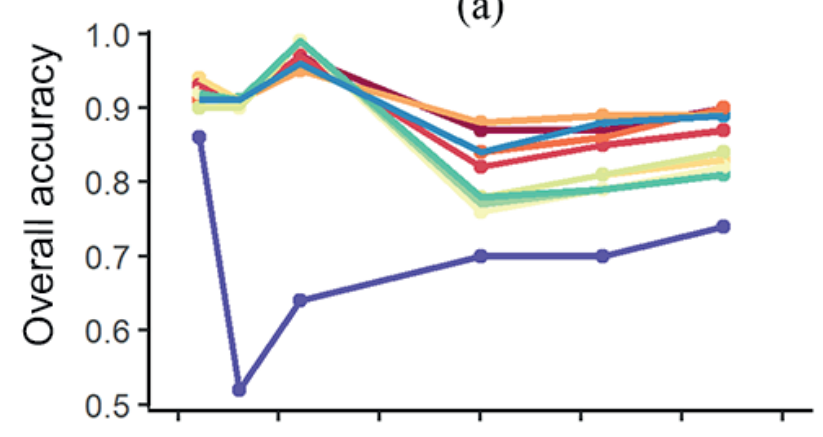

Vegetation indices
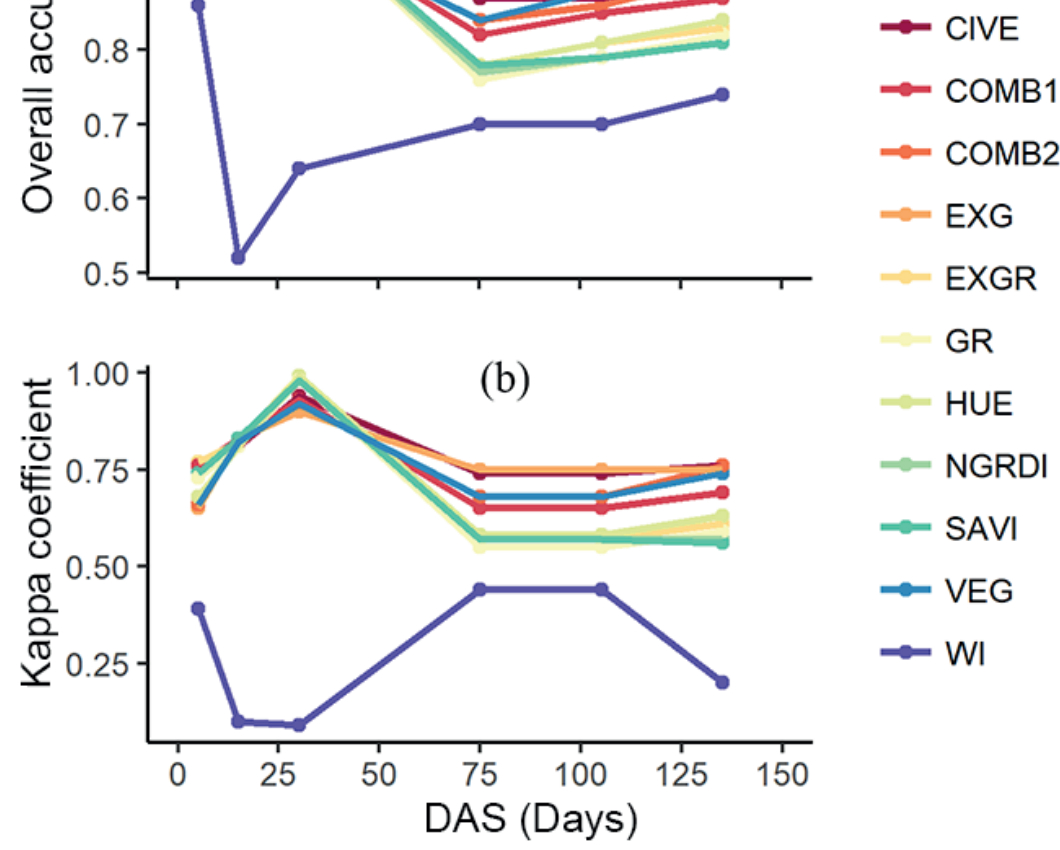

GR

$\simeq$ HUE

$\simeq$ NGRDI

$=$ SAVI

$\leadsto$ VEG

$\rightarrow$ WI

Vegetation cover indices obtained by vegetation significance, except for the index WI (Table 3). The indices and Stocking method indices that presented a good performance are those

The linear regression between Stocking vegetation indices and those calculated from vegetation indices presented different behaviors in relation to cover plants. For jack bean, correlations presented a high predictive power, with regressions that also presented a higher value of Kappa and overall accuracy. The index EXG presented an $\mathrm{R}^{2}$ of 0.85 and a correlation coefficient of 0.92 , followed by the index CIVE, which showed an $\mathrm{R}^{2}$ of 0.80 and a correlation coefficient of 0.92 .

with high coefficients of determination and statistical 
Table 3. Description of the analyzed models related to cover indices calculated among vegetation indices (x) and the Stocking method (y) for the cover plants jack bean and millet.

\begin{tabular}{|c|c|c|c|c|c|c|}
\hline Model & Cover plant & Vegetation index & Linear regression & $\mathrm{R}^{2}$ & p-value & $\mathrm{RSS}^{1}$ \\
\hline 1 & \multirow{11}{*}{ Jack bean } & CIVE & $y=0.75 x+0.10$ & 0.84 & $<0.001$ & 0.1306 \\
\hline 2 & & COMB1 & $y=0.79 x+0.09$ & 0.81 & $<0.001$ & 0.0119 \\
\hline 3 & & COMB2 & $y=0.80 x+0.94$ & 0.82 & $<0.001$ & 0.0007 \\
\hline 4 & & EXG & $y=0.75 x+0.11$ & 0.85 & $<0.001$ & 0.0114 \\
\hline 5 & & EXGR & $y=0.78 x+0.86$ & 0.83 & $<0.001$ & 0.0043 \\
\hline 6 & & NGRDI & $y=0.79 x+0.08$ & 0.82 & $<0.001$ & 0.0004 \\
\hline 7 & & VEG & $y=0.78 x+0.11$ & 0.82 & $<0.001$ & 0.0102 \\
\hline 8 & & WI & $y=0.92 x+0.47$ & 0.52 & $<0.001$ & 1.8873 \\
\hline 9 & & HUE & $y=0.85 x+0.02$ & 0.84 & $<0.001$ & 2.1118 \\
\hline 10 & & GR & $y=0.79 x+0.08$ & 0.82 & $<0.001$ & 0.0109 \\
\hline 11 & & SAVI & $y=0.80 x+0.08$ & 0.82 & $<0.001$ & 0.0001 \\
\hline 12 & \multirow{11}{*}{ Millet } & CIVE & $y=0.55 x+0.29$ & 0.46 & 0.002 & 0.3132 \\
\hline 13 & & COMB1 & $y=0.54 x+0.32$ & 0.40 & 0.004 & 0.0277 \\
\hline 14 & & COMB2 & $y=0.58 x+0.27$ & 0.47 & 0.002 & 0.0542 \\
\hline 15 & & EXG & $y=0.56 x+0.28$ & 0.47 & 0.001 & 0.0061 \\
\hline 16 & & EXGR & $y=0.40 x+0.41$ & 0.26 & 0.030 & 0.2298 \\
\hline 17 & & NGRDI & $y=0.36 x+0.42$ & 0.23 & 0.045 & 0.0036 \\
\hline 18 & & VEG & $y=0.57 x+0.29$ & 0.46 & 0.001 & 0.3211 \\
\hline 19 & & WI & $y=3.21 x+0.31$ & 0.34 & 0.010 & 1.1613 \\
\hline 20 & & HUE & $y=0.42 x+0.37$ & 0.37 & 0.007 & 1.068 \\
\hline 21 & & GR & $y=0.38 x+0.40$ & 0.32 & 0.014 & 0.0056 \\
\hline 22 & & SAVI & $y=0.39 x+0.40$ & 0.33 & 0.012 & 0.0006 \\
\hline
\end{tabular}

${ }^{1}$ Residual sum of squares between the cover index determined by the Stocking method and that calculated from vegetation indices.

The coefficients of determination were low for millet, with regressions without a statistical significance. The indices CIVE, COMB2, and EXG presented the highest values of $\mathrm{R}^{2}$ and correlation coefficient, with values of 0.68 and 0.47 , respectively. These results are due to the short millet cycle and/or to a higher jack bean leaf area, allowing a more contrasting vegetation cover. In addition, the indices EXG, CIVE, VEG, and COMB2 presented a Pearson correlation coefficient higher than 0.90 for jack bean and 0.68 for millet.

Regarding the adjustment of vegetation cover index dynamics obtained by both methods, high values of RSS were observed for HUE and WI for jack bean and millet (Table 3). The higher the RSS value is, the greater the discrepancy between the assessed methods. Subsequently, the indices CIVE, COMB1, EXG, GR, and VEG presented intermediate RSS values for jack bean, ranging from 0.01 to 0.13 . The lowest values were obtained by EXGR, COMB2, NGRDI, and SAVI. Regarding the millet, the indices VEG, CIVE, EXGR, COMB2, and COMB1 presented values between 0.0277 and 0.3211 , being the lowest value observed by EXG, GR, NGRDI, and SAVI. Thus, SAVI stood out as the index that most approached the standard Stocking method in both studied crops.

The relationship between vegetation cover indices (Stocking and CI VI) over DAS is shown in Figure 7 for jack bean and in Figure 8 for millet. The index WI presented an over or overestimation of Stocking vegetation index regarding CI VI for both covers. For the others, in general, the temporal dynamics of cover indices presented a similar tendency between both methods by both cover plants, with greater discrepancies (overestimation) 
occurring for millet as DAS increased. Moreover, calculated from the vegetation index was observed an overestimation of the vegetation cover index in both crops, except for the index WI (Figure 7).

Figure 7. Comparison between vegetation cover indices calculated by the Stocking method (Stocking CI) and from the vegetation indices (CI VI) CIVE (a), COMB1 (b), COMB2 (c), ExG (d), EXGR (e), GR (f), HUE (g), NGRDI (h), SAVI (i), VEG (j), and WI (k) for jack bean as a function of days after sowing (DAS).

(a)

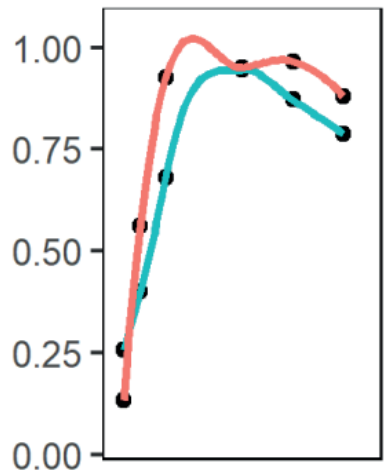

(e)

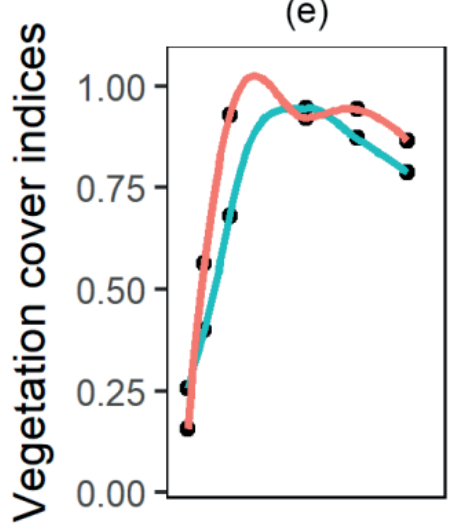

(i)

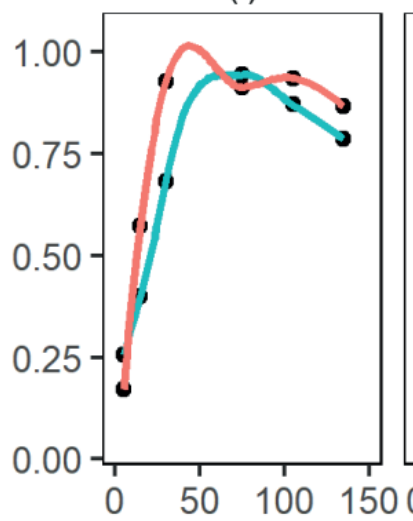

(b)

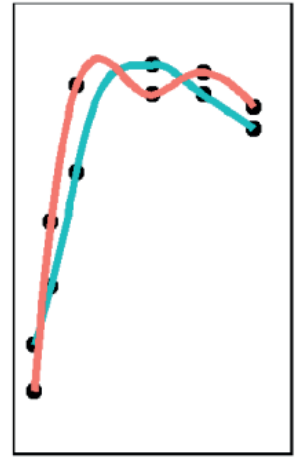

(f)

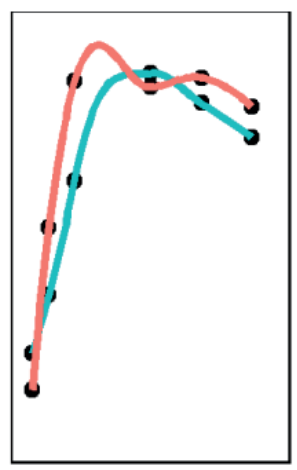

(j)

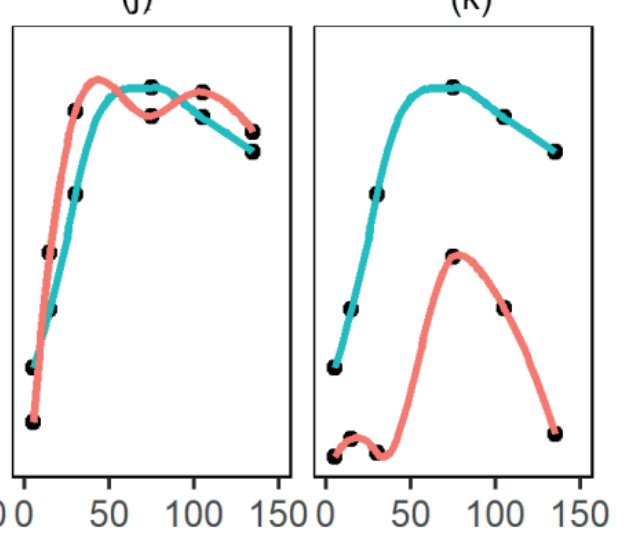

(c)

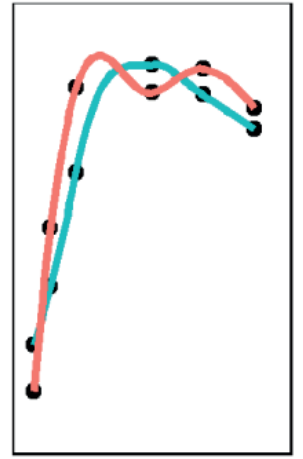

(g)

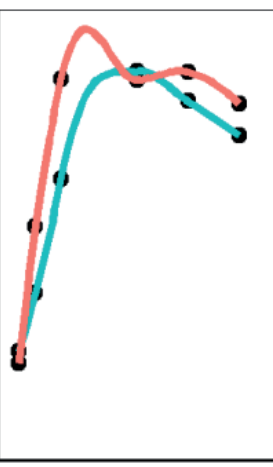

(k)

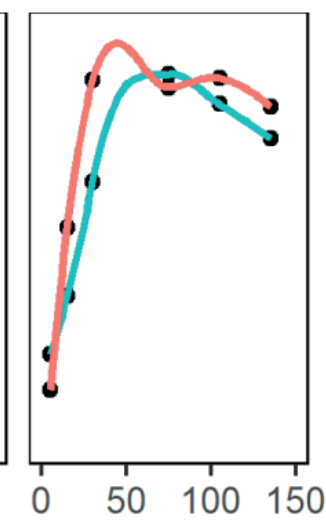

— Stocking $-\mathrm{Cl}$ VI

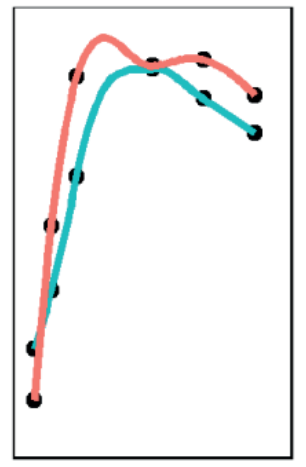

(h)

DAS (Days) 
Figure 8. Comparison between vegetation cover indices calculated by the Stocking method (Stocking CI) and from the vegetation indices (CI VI) CIVE (a), COMB1 (b), COMB2 (c), ExG (d), EXGR (e), GR (f), HUE (g), NGRDI (h), SAVI (i), VEG (j), and WI (k) for millet as a function of days after sowing (DAS).

(a)

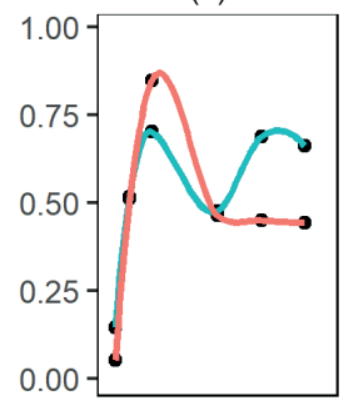

(e)

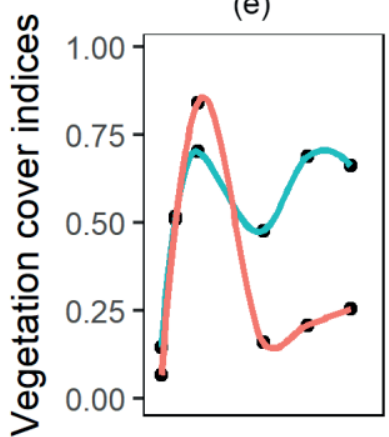

(i)

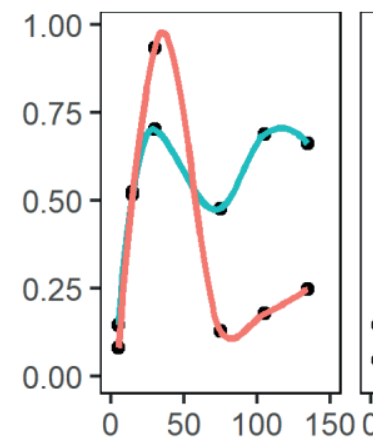

(b)

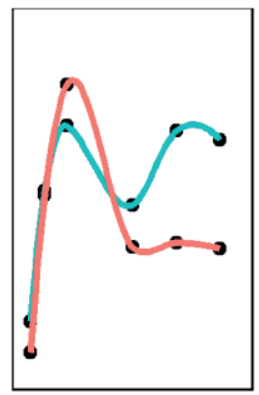

(f)

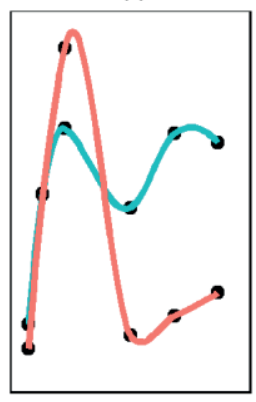

(j) (c)

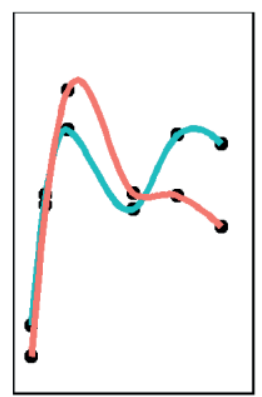

(g)

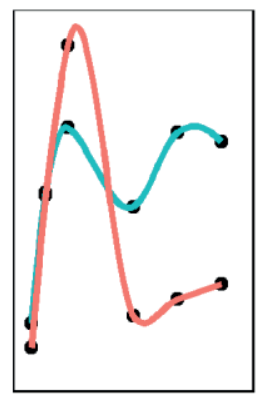

(k) (d)

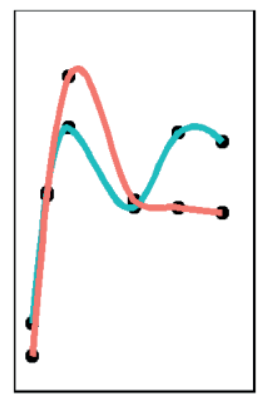

(h)

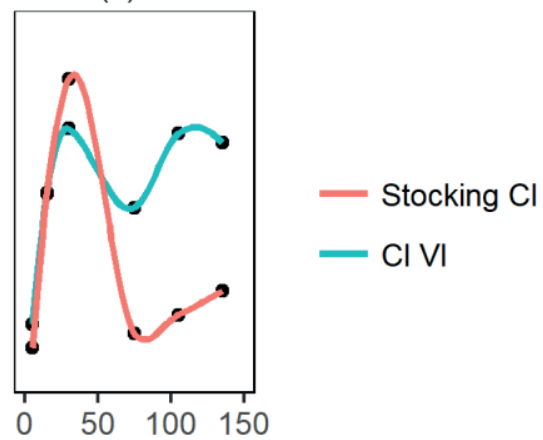

The difference between vegetation cover index estimation methods tends to decrease as the crop cycle advanced, which can be explained by plant size, change in cover index, and plant senescence at the end of the cycle. According to Kazmi et al. (2015), the highest accuracy of vegetation classification occurs at the early crop stages, allowing a better estimation of the cover index.
The differences observed between both methods of calculating vegetation cover index can be explained by the difference in the nature to which the data are collected since the Stocking method considers three diagonal lines in each plot to calculate the average index value. In contrast, vegetation cover indices calculated from vegetation index represent, in pixel-based maps (information exhaustively discussed), the plots in their totality. 


\section{Conclusions}

The vegetation indices CIVE and EXG presented a better performance and the index WI presented the worst performance regarding the vegetation classification during jack bean and millet cycles, according to the overall accuracy and Kappa coefficient. Vegetation indices were an effective tool in obtaining soil cover indices when compared to the standard Stocking method, except for the index WI.

Architecture and cycle of millet and jack bean influenced the behavior of the studied vegetation indices.

We recommend the use of UAVs with onboard digital cameras in the visible (RGB) to obtain vegetation cover indices due to the following factors: a) vegetation indices could be obtained quickly, with a higher spatial cover; b) vegetation indices showed good correlations with vegetation cover indices, especially for jack bean; c) the high dynamism of UAVs allow a higher temporal resolution; and d) relatively lower costs of onboard digital cameras in the visible (RBG).

\section{Acknowledgments}

We are grateful to The World Academy of Sciences (TWAS), the National Council for Scientific and Technological Development (CNPq) (processes 190119/2013-6, 202938/20182, 471522/2012-0, and 306511/2017-7), the Coordination for the Improvement of Higher Education Personnel (CAPES), and the Minas Gerais Research Foundation (FAPEMIG) (processes CAG-PPM-00422-13, CAG-APQ-00802-18, APQ-01423-11, and CAG-APQ-01053-15) for the financial support and for granting the scholarships. We are also grateful to the contributions of Mike R. James and John N. Quinton, Professors of the Lancaster Environment Centre of the Lancaster University, Lancaster (UK), for the technical support in using UAVs and associated software. We would also like to thank the student Wellington de Lima of the UFLA Agronomy course and a fellow in the institutional program of initiation in technological development and innovation of $\mathrm{CNPq}$, responsible for piloting in the UAV.

\section{References}

AGISOFT. Agisoft PhotoScan User Manual. Petersburg: Agisoft LLC, 2017. Available at: <www.agisoft. ru> Accessed at: 6 aug. 2017.

ARROYO, J.; GUIJARRO, M.; PAJARES, G. An instance-based learning approach for thresholding in crop images under different outdoor conditions. Computers and Electronics in Agriculture, Athens, v. 127, p. 669679, 2016.

BENDIG, J.; YU, K.; AASEN, H.; BOLTEN, A.; BENNERTZ, S.; BROSCHEIT, J.; GNYP, M. L.; BARETH, G. Combining UAV-based plant height from crop surface models, visible, and near infrared vegetation indices for biomass monitoring in barley. International Journal of Applied Earth Observation and Geoinformation, Amsterdam, v. 39, p. 79-87, 2015.

CAMPBELL, J. B.; WYNNE, R. H. Digital imagery. In: CAMPBELL, J. B.; WYNNE, R. H. (Ed.). Introduction to remote sensing. $5^{\text {th }} \mathrm{ed}$. New York: The Guilford Press, 2011, p. 101-130.

CARDOSO, D. P.; SILVA, M. L. N.; CARVALHO, G. J. de; FREITAS, D. A. F. de; AVANZI, J. C. Plantas de cobertura no controle das perdas de solo, água e nutrientes por erosão hídrica. Revista Brasileira de Engenharia Agrícola e Ambiental, Campina Grande, v. 16, n. 6, p. 632-638, 2012.

CARUSO, G.; TOZZINI, L.; RALLO, G.; PRIMICERIO, J.; MORIONDO, M.; PALAI, G.; GUCCI, R. Estimating biophysical and geometrical parameters of grapevine canopies ('Sangiovese') by an unmanned aerial vehicle (UAV) and VIS-NIR cameras. Vitis - Journal of Grapevine Research, Siebeldingen, v. 56, n. 2, p. 63-70, 2017.

DANDOIS, J. P.; OLANO, M.; ELLIS, E. C. Optimal altitude, overlap, and weather conditions for computer vision UAV estimates of forest structure. Remote Sensing, Basel, v. 7, n. 10, p. 13895-13920, 2015.

FAUSTOLO, D.; BISPO, A.; LEANDRO, M.; SILVA, N.; PONTES, L. M.; GUIMARÃES, D. V. Soil, water, nutrients and soil organic matter losses by water erosion as a function of soil management in the Posses subwatershed, Extrema, Minas Gerais, Brazil. Semina: 
Ciências Agrarias, Londrina, v. 38, n. 4, p. 1813-1824, 2017.

FERREIRA, D. F. Estatística básica. Lavras: Editora UFLA, 2005. 664 p.

FOODY, G. Assessing the accuracy of remotely sensed data: principles and practices. The Photogrammetric Record, Nottingham, v. 25, n. 130, p. 204-205, 2010.

GILABERT, M.; GONZÁLEZ-PIQUERAS, J.; GARCÍA-HARO, F.; MELIÁ, J. A generalized soil-adjusted vegetation index. Remote Sensing of Environment, Amsterdam, v. 82, n. 2-3, p. 303-310, 2002.

GUIJARRO, M.; PAJARES, G.; RIOMOROS, I.; HERRERA, P. J.; BURGOS-ARTIZZU, X. P.; RIBEIRO, A. Automatic segmentation of relevant textures in agricultural images. Computers and Electronics in Agriculture, Athens, v. 75, n. 1, p. 75-83, 2011.

GUIMARAES, D. V.; SILVA, M. L. N.; BISPO, D. F. A.; MARTINS, S. G.; MELO NETO, J. D. O.; MARTINS, R. P.; CURI, N. Water erosion associated with rainfall patterns in the extreme South of Bahia in eucalyptus post-planting. Semina: Ciências Agrárias, Londrina, v. 38, n. 4, p. 2463, 2017. Supplement 1.

HAGUE, T.; TILLETT, N. D.; WHEELER, H. Automated crop and weed monitoring in widely spaced cereals. Precision Agriculture, Berlin, v. 7, n. 1, p. 21-32, 2006.

HILBE, J. M. Logistic regression models. New York: Taylor \& Francis.2009. 53 p.

HUNT, E. R. Evaluation of digital photography from model aircraft for remote sensing of crop biomass and nitrogen status. Precision Agriculture, Berlin, v. 6, n. 4, p. 359-378, 2005.

JAFARI GOLDARAG, Y.; MOHAMMADZADEH, A.; ARDAKANI, A. S. Fire risk assessment using neural network and logistic regression. Journal of the Indian Society of Remote Sensing, Berlin, v. 44, n. 6, p. 885-894, 2016.

KATAOKA, T.; KANEKO, T.; OKAMOTO, H.; HATA, S. Crop growth estimation system using machine vision. Proceedings 2003 IEEE/ASME International Conference on Advanced Intelligent Mechatronics, Kobe, v. 2, n. 1, p. 1079-1083, 2003.

KAZMI, W.; GARCIA-RUIZ, F. J.; NIELSEN, J.; RASMUSSEN, J.; JØRGEN ANDERSEN, H. Detecting creeping thistle in sugar beet fields using vegetation indices. Computers and Electronics in Agriculture, Athens, v. 112, p. 10-19, 2015.

LANDIS, J. R.; KOCH, G. G. The Measurement of observer agreement for categorical data. Biometrics, Washington, v. 33, n. 1, p. 159, 1977.
LI, Y.; CHEN, D.; WALKER, C. N.; ANGUS, J. F. Estimating the nitrogen status of crops using a digital camera. Field Crops Research, Amsterdam, v. 118, n. 3, p. 221-227, 2010.

LIMA, P. L. T.; SILVA, M. L. N.; CURI, N.; QUINTON, J. Soil loss by water erosion in areas under maize and jack beans intercropped and monocultures. Ciência $e$ Agrotecnologia, Lavras, v. 38, n. 2, p. 129-139, 2014.

MARCHANT, J. A.; ONYANGO, C. M. Shadowinvariant classification for scenes illuminated by daylight. Journal of the Optical Society of America, Washington, v. 17, n. 11, p. 1952-1961, 2000.

MARRERO, D. F; DELGADO, L. E. P.; IAÑEZ, N. C.; CALERO, C. M.; RODRÍGUEZ, M. L.; PÉREZ, L. R.; RODRÍGUEZ, L. C. Cubierta vegetal con Teramnus labialis en plantaciones citrícolas: efectos sobre algunas propiedades físicas del suelo. Semina: Ciências Agrárias, Londrina, v. 30, n. 4, p. 1073, 2009. Supplement 1.

MEYER, G. E.; NETO, J. C. Verification of color vegetation indices for automated crop imaging applications. Computers and Electronics in Agriculture, Athens, v. 63, n. 2, p. 282-293, 2008.

MOTOHKA, T.; NASAHARA, K. N.; OGUMA, H.; TSUCHIDA, S. Applicability of green-red vegetation index for remote sensing of vegetation phenology. Remote Sensing, Amsterdam, v. 2, n. 10, p. 2369-2387, 2010.

PASSOS, R. R.; COSTA, L. M.; BURAK, D. L.; SANTOS, D. A. Quality indices in degraded pasture in hilly relief. Semina: Ciências Agrárias, Londrina, v. 36, n. 4, p. 2465-2482, 2015.

PURCELL, L. C.; MOZAFFARI, M.; KARCHER, D. E.; ANDY KING, C.; MARSH, M. C.; LONGER, D. E. Association of "Greenness" in corn with yield and leaf Nitrogen concentration. Agronomy Journal, Madison, v. 103, n. 2, p. 529-535, 2011.

SABERIOON, M. M.; AMIN, M. S. M.; ANUAR, A. R.; GHOLIZADEH, A.; WAYAYOK, A.; KHAIRUNNIZABEJO, S. Assessment of rice leaf chlorophyll content using visible bands at different growth stages at both the leaf and canopy scale. International Journal of Applied Earth Observation and Geoinformation, Amsterdam, v. 32, p. 35-45, 2014.

SANTOS, C. A. G.; SUZUKI, K.; WATANABE, M.; SRINIVASAN, V. S. Influência do tipo da cobertura vegetal sobre a erosão no semi-árido Paraibano. Revista Brasileira de Engenharia Agrícola e Ambiental, Campina Grande, v. 4, n. 1, p. 92-96, 2000.

SPERANDIO, H. V.; CECÍlLIO, R. A.; CAMPANHARO, W. A.; CARO, C. F. DEL; HOLLANDA, M. P. DE. 
Avaliação da erosão hidrica pela alteração na superfície do solo em diferentes coberturas vegetais de uma sub-bacia hidrográfica no Município de Alegre, ES. Semina:Ciâncias Agrarias, Londrina, v. 33, n. 4, p. 14110-1418, 2012.

STOCKING, M. A. Assessing vegetative cover and management effects. In: LAL, R. (Ed.). Soil erosion research methods. 2. ed. Ankeny: Soil and Water Conservation Society, 1994. p. 163-185.

TORRES-SÁNCHEZ, J.; PEÑA, J. M.; CASTRO, A. I. DE; LÓPEZ-GRANADOS, F. Multi-temporal mapping of the vegetation fraction in early-season wheat fields using images from UAV. Computers and Electronics in Agriculture, Athens, v. 103, p. 104-113, 2014.

TUCKER, C. J. Red and photographic infrared linear combinations for monitoring vegetation. Remote Sensing of Environment, Amsterdam, v. 8, n. 2, p. 127-150, 1979.
WOEBBECKE, D. M.; MEYER, G. E.; BARGEN, K. V. O. N.; MORTENSEN, D. A. Color indices for weed identification under various soil, residue, and lighting conditions. Transactions of the ASAE, Michigan, v. 38, n. 1, p. 259-269, 1995.

YU, Z.; CAO, Z.; WU, X.; BAI, X.; QIN, Y.; ZHUO, W.; XIAO, Y.; ZHANG, X.; XUE, H. Automatic imagebased detection technology for two critical growth stages of maize: Emergence and three-leaf stage. Agricultural and Forest Meteorology, Amsterdam, v. 174-175, p. 6584, 2013.

ZHENG, Y.; ZHU, Q.; HUANG, M.; GUO, Y.; QIN, J. Maize and weed classification using color indices with support vector data description in outdoor fields. Computers and Electronics in Agriculture, Athens, v. 141, p. 215-222, 2017.

ZHONGMING, W.; LEES, B. G.; FENG, J.; WANNING, L.; HAIJING, S. Stratified vegetation cover index: A new way to assess vegetation impact on soil erosion. Catena, Amsterdam, v. 83, n. 1, p. 87-93, 2010. 
